\title{
Paradoxes of China's Economic Boom
}

\section{Citation}

Whyte, Martin King. 2009. "Paradoxes of China's Economic Boom." Annual Review of Sociology 35 (1): 371-92. https://doi.org/10.1146/annurev-soc-070308-115905.

\section{Permanent link}

http://nrs.harvard.edu/urn-3:HUL.InstRepos:37968246

\section{Terms of Use}

This article was downloaded from Harvard University's DASH repository, and is made available under the terms and conditions applicable to Open Access Policy Articles, as set forth at http:// nrs.harvard.edu/urn-3:HUL.InstRepos:dash.current.terms-of-use\#OAP

\section{Share Your Story}

The Harvard community has made this article openly available.

Please share how this access benefits you. Submit a story.

Accessibility 


\title{
Paradoxes of China's Economic Boom
}

\author{
Martin King Whyte
}

Department of Sociology, Harvard University, Cambridge, Massachusetts 02138; email: mwhyte@wjh.harvard.edu

Annu. Rev. Sociol. 2009. 35:371-92

The Annual Review of Sociology is online at soc.annualreviews.org

This article's doi:

10.1146/annurev-soc-070308-115905

Copyright (C) 2009 by Annual Reviews.

All rights reserved

0360-0572/09/0811-0371\$20.00

\section{Key Words}

development, postsocialist transition, developmental state, market reforms, property rights

\begin{abstract}
China's stunning economic performance for the past three decades was not only unexpected but contradicts much received wisdom in the study of development. Four paradoxes posed by China's record are critically examined: (a) China's traditional culture and institutions as obstacles to development; $(b)$ the necessity of big bang comprehensive reforms to transform a centrally planned economy into a market economy; (c) the perils of state-directed economic development (especially when the state is composed of lifelong communist bureaucrats); and (d) the necessity of getting the institutions right in order to foster development, particularly by establishing secure private property rights. Reasons why China was able to defy expectations and the received wisdom and develop so successfully are discussed. The Chinese case indicates that countries cannot succeed at development by a standard cookbook approach but must tailor their development policies and institutions to their distinctive history, potentials, and limitations.
\end{abstract}


For the past three decades, China has experienced an extraordinary economic boom. Economic growth rates averaging close to $10 \%$ a year have been maintained despite serious bumps in the road, such as foreign sanctions after the 1989 Tiananmen massacre and the 1997 Asian financial crisis. Hundreds of millions of mostly rural Chinese citizens have been lifted out of grinding poverty, and rapidly growing middle and wealthy classes now enjoy consumption levels that are approaching First World standards. Multiple other indicators convey the spectacular successes of China's economic boom. For example, China went from having negligible foreign direct investment at the time Mao Zedong died in 1976 to being the developing world's largest recipient of foreign direct investment in recent years. China in the same period went from having essentially zero foreign exchange reserves to having the world's largest accumulation (with close to US\$2 trillion in 2008). The country that in 1958 provoked a combination of pity and amusement with its failed attempt to use backyard steel furnaces to catch up with Great Britain in steel production has since the mid-1990s been by far the world's largest producer of steel. Similarly, China went from producing limited ranges of very unstylish clothing (Would you like your Mao-jacket and pants in blue, gray, or olivegreen?) to being the major provider of inexpensive but relatively stylish clothing marketed around the world; a nation that had virtually no privately owned cars in 1976 now has more than 9 million sold each year, with more Buicks purchased annually by Chinese consumers than by Americans. As a symbolic tribute to China's development success, when the World Bank appointed a new chief economist in 2008 , the post went to a Chinese researcher, Justin Yifu Lin, rather than to a Western economist (although having a PhD from the University of Chicago may have helped).

What are the explanations for China's dramatic turnaround and spectacular economic successes of recent decades? This success was unexpected at the time China's reforms were launched in 1978. After all, who would have thought that lifelong communist bureaucrats could successfully direct the transformation from an increasingly inefficient centrally planned system to a vibrant market economy? In multiple respects China's approach to economic development contradicts received wisdom on how to pursue growth. In reading the existing literature on economic development, one thinks of the analogy between China's economic performance and the bumblebeeby all rights it should not be able to fly, but nonetheless it does, and in fact it soars spectacularly! By considering briefly several strands of past research on China and economic development, and then by examining key features of China's approach in the post-1978 period, this review attempts to contribute to an expanded debate about economic development possibilities in the contemporary world. The primary generalizations to be critically examined here in light of China's experiences are the following:

- China's traditional institutions and culture as obstacles to economic development;

- The need for comprehensive, big bang market reforms in order to successfully dismantle a centrally planned socialist economy;

- The necessity of undergoing a dual transition from state management to markets and from autocracy to democracy, while avoiding a variety of perils of statedirected economic development;

- The imperative to get the institutions right by adopting the institutions and policies required in a modern market society, particularly secure private property rights.

\section{FROM DEVELOPMENT FAILURE TO DEVELOPMENT SUCCESS}

The first paradox concerning China's recent economic boom is that this is the society about 
which a considerable literature accumulated over the years as a case study in economic development failure-indeed, failure not once but twice. The first failure involves the fact that, although China was in many respects more developed than Western societies until as late as the eighteenth century, subsequently it was England that launched the industrial revolution, while China failed to do so. The second failure involves the fact that when both China and Japan were presented with military and economic challenges from Britain and other Western powers in the nineteenth and early twentieth centuries, Japan rose to the challenge through reforms that launched it on a path to becoming a modern industrial power, while China failed to do so. How did a country that was a case study of economic development failure become so successful, and what does this turnaround say about the assertions in the existing literature?

The most famous analysis of China's first failure was, of course, developed by Max Weber in works such as The Protestant Ethic and the Spirit of Capitalism (1930 [originally 1905]) and The Religion of China (1951 [originally 1915]). Weber contended that although Chinese culture was in many ways sophisticated and imbued with a fairly high level of rationality, it nonetheless was in key respects deficient in the institutions and values necessary to allow modern capitalism to arise-for example, with a culture stressing reverence for the past, stability, and harmony rather than openness to change and the pursuit of individual selfinterest; denigration of merchants and weak development of urban political autonomy and social classes; strong family obligations that generally trumped rational economic calculations; and weak development of scientific experimentation and rationality (all in comparison with preindustrial Western Europe, and with England in particular). This intellectual tradition is still very much alive-for example in the recent works of David Landes (e.g., Landes 2003) on the advantages Western Europe gained from greater historical skill at, and comfort with, technological tinkering and scientific experimentation.

Not all explanations of China's first failure at economic development adopt this cultural deficiency framework, however. Elvin (1973) coined the term "high level equilibrium trap" to refer to his claim that the late imperial Chinese commercial system was so sophisticated and responsive to changes in demand and supply that severe shortages and bottlenecks that might have stimulated technological breakthroughs (for example, a shift from household weaving to factory textile production) were avoided. Thus, for Elvin, China was a victim of its own success in constructing over the centuries a highly effective and responsive preindustrial economic system. A more recent critique of the cultural deficiency approach to explaining China's first failure at development has been presented by Pomeranz (2000), whose argument in oversimplified form says that England had two key resources that China lacked-coal and colonies. China did have ample coal deposits, but unlike England these were located far away from the coastal cities where textile and other factories might be established, and China lacked any means to transport the coal from the interior to the coast quickly and cheaply. In addition, English colonies provided both manufacturing inputs and finances to fuel growing factories without putting excessive burdens on the domestic population.

Works dealing with China's second failure-her inability to match Japan's economic response to the West in the nineteenth and early twentieth centuries-generally can also be divided into those that take a cultural deficiency approach and those that do not. In terms of the former, Bellah (1957) argued that by historical chance Japan was endowed with a rough functional equivalent of the Protestant ethic in its own samurai code and that, through reforms that eliminated Japan's feudal estates, that society was able to turn many former samurai toward becoming entrepreneurial merchants. By implication, China was less successful in responding to the West because 
she lacked the cultural basis for a constructing a new and proud entrepreneurial class. Levy (1955; see also Rozman 1981) argued that Japan benefited from having stronger merchant family traditions than China as well as from key differences in traditional family patterns. Specifically, Japanese families, unlike the Chinese with their custom of partible inheritance, had to settle on a male heir to succeed the father as head of the main family. Although most often the oldest son became the family head, if that son was deemed insufficiently capable, another son could become the chosen heir, or in some cases the family would even adopt a boy from outside to become the heir in preference to their own biological sons. Thus, for Levy, in the Japanese family system competence trumped kinship, rather than the other way around as he claimed was the case in China.

Again, other works adopt alternatives to cultural deficiencies to explain the second failure of China to develop. In particular, the weakness, incompetence, and venality of successive governments in China in the period 1840-1949 and the prolonged and damaging distractions caused by political chaos, warfare, and foreign invasion posed severe obstacles to any successful response to the West (see Coble 1980, Feuerwerker 1977, Perkins 2004, Rawski 1989), a situation that contrasts sharply with Japan's experience of state strength and greater political stability in the same period.

Studies of the sort cited here have been sharply criticized in recent years. Some of the criticisms challenge whether the first question posed-Why did the industrial revolution occur in England rather than in China?-is a reasonable or useful question in the first place. However, the most frequent criticism is a fairly obvious one: that track records of economic development since 1950 make the idea of Chinese cultural deficiencies implausible. The most dynamic region in the world economy in this period has been East Asia, and the successful cases either are mainly Chinese (Taiwan, Hong Kong, Singapore, and now China), or share with China a strong tradition of
Confucian values (Japan, South Korea, Vietnam). These successes do not, of course, explain why it was England and not China that developed modern capitalism first. However, they do very much undermine the case that China's second failure at development was due to cultural deficiencies.

Indeed, the predictable result of East Asian development successes has been the appearance of a new genre of revisionist accounts in which the cultural advantages shared by Chinese societies help to explain their recent developmental success (see, for example, Arkush 1984, Gates 1996, Harrell 1985, Redding 1990, Wong 1998). In some instances, the same set of traditional institutional arrangements and values that were previously described as an obstacle to development have been reinterpreted as an engine of development (see Whyte 1996 on Chinese family patterns). One recent study of the strong market and business orientations present in ordinary Chinese villages over the centuries makes the following claim: "The argument is a statistical one. Take two populations of children with similar distributions of intelligence and access to schooling. One population is reared in Chinese villages; the other, in some other cultural venue (medieval Europe, contemporary Bihar or Bangladesh) at a similar level of economic development. The hypothesis is that, upon maturity, the former population will display a stronger array of market skills and accomplishments than the latter" (Rawski 2007, p. 103). (For recent discussions of the role of culture in economic development, see Clark 2007, Harrison \& Huntington 2000.)

In short, both the record of East Asian economic trends since 1950 and these revisionist analyses provide grounds to discount the claim that China's spotty economic development record prior to 1978 can be attributed to the ways in which China's traditional culture lacked or contradicted elements necessary for modern economic development. Other explanations, such as a weak and ineffective state combined with military conflict prior to 1949 and misguided state policies in the 
1949-1978 period seem more plausible as obstacles to China's economic success prior to $1978 .{ }^{1}$

\section{HOW TO CARRY OUT MARKET REFORMS OF A SOCIALIST ECONOMY}

The second paradox under scrutiny here is that China's approach to reforming its centrally planned economy after 1978 contradicts the advice of most economic experts about how this should be done. In oversimplified form, this has been posed as a debate between a big bang approach (also called shock therapy) to dismantling a centrally planned economy and a more gradualist or step-by-step approach, with Eastern Europe pursuing the former approach while China stuck to the latter. The big bang approach entails dismantling all elements of centrally planned socialist institutions as quickly as possible and replacing them with the institutions of a capitalist economy through privatization of property and enterprises, freeing prices and allowing them to be set by market forces, establishing stock markets, reducing or eliminating monopolies and subsidies and fostering market competition, opening the economy to the outside world, making the national currency convertible, and so forth. The gradualist approach entails adopting some market-oriented reforms while maintaining intact much of the socialist planned economy for an extended period of time. For example, in the Chinese case agriculture was subjected to market reforms

\footnotetext{
${ }^{1}$ It should be noted that China's second failure was only relative, not absolute. During the few relatively peaceful periods in the first half of the twentieth century, Republican China registered important progress in industrialization, transportation, and popular consumption (see Rawski 1989), and by most economic development indicators the People's Republic of China was considerably more developed in 1978 than it had been in 1949 (see, for example, Howe 1978; Naughton 1991, 2007), with a growth rate of roughly $4 \%$ per year between 1957 and 1978 (Perkins 2004). In terms of the latter period, as in other centrally planned economies, this progress was reflected much more in industrial production, transportation, and access to education than in consumption of food and consumer goods.
}

before urban state industry was, but even in agriculture land was not (and still has not been) privatized, even as family farming and private enterprise activity were allowed for the first time since the creation of Chinese socialism in 1955. Early on, Chinese enterprises were opened up to some kinds of foreign investments (and in certain locales) but not to others, China's newly created stock markets remain state dominated and heavily regulated affairs, and China's currency is still managed rather than freely traded in global currency markets.

Why did most experts advocate the big bang approach? The most articulate critic of gradualism was Hungarian economist Janos Kornai (see Kornai 1990, 1992), although his thinking was widely echoed by economists in the World Bank and in Western academic institutions, some of whom played key roles as advisors to East European governments launching postsocialist transitions after 1989. There were two main problems with a gradualist approach, according to Kornai and others. First, the continued operation of a substantial portion of the economy under the centrally planned system would sustain the irrationalities and inefficiencies of that system while sending out the wrong signals to influence decision making in the new market-oriented and privatized sectors of the economy. In other words, the primary efficiency gains expected in a market system would be undermined insofar as a significant planned economy sector continued to operate. The second major problem was that the prolonged coexistence of both planned and market sectors of the national economy would open up excessive corruption opportunities, as powerful individuals in the planned economy could use their control over fixed-price resources in that sector and over opportunities in the market sector to engage in rent seeking and profiteering. So Kornai and others argued it would be better to make a full transition to a market system as rapidly as possible so that the efficiency benefits of such a system could be fully realized (see also Murphy et al. 1992, Sachs \& Woo 1994; for a contrary view, however, see Stiglitz 1994). 
Why did China not follow expert advice and pursue a big bang approach? First there was simply the question of timing. China launched its market reform program in 1978, before market reforms were even on the agenda in the Soviet Union and Eastern Europe. ${ }^{2}$ Because nobody at the time saw the possibility for centrally planned socialist economies to be transformed into market economies, an orthodoxy about how to engineer such a transformation had not yet emerged.

However, perhaps the major reason China defied the experts is that a big bang comprehensive approach to market transformation was not feasible politically in China in 1978 . Any attempt then to comprehensively replace centrally planned socialism with market institutions would have generated enormous resistance within the Chinese party and state bureaucracy that would have had to implement such changes, resistance based upon decades of indoctrination in, and dedication to, establishing socialism. After all, economic reforms in Eastern Europe followed in the wake of the collapse of Communist Party rule, whereas in China economic reforms were launched in the hope of staving off such a collapse. But how to carry out the market transformation of a planned economy in a socialist society still ruled by a Communist Party was a tricky proposition. Only a partial and gradual approach to market reforms was feasible, an approach premised on a strategy of demonstrating the superior performance of those sectors freed from the planned system and thereby generating increased support for widening the scope of market distribution. ${ }^{3}$ Even then (and still today) these changes had to be ideologically justified in terms of fig-leaf formulas such as socialist market economy.

Even if a comprehensive approach to market transformation was never in the cards in China, larger questions remain: Why did China's strategy of partial and gradual reforms work so well despite the warnings of economic experts, and why in contrast was the big bang approach so much less successful when it was tried in Russia and Eastern Europe? No attempt is made here to answer this second question beyond saying that advocates of the big bang approach did not recognize sufficiently the virtually insurmountable obstacles to creating the full panoply of market institutions quickly and the potentially disastrous consequences that would ensue during the chaos created by attempting to do so (seen most glaringly in the way Russian privatization of state industrial assets created new capitalist oligarchs). ${ }^{4}$ Political problems also contributed to the chaos: The collapse of rule by communist parties and of state authority generally and the relative weakness of new, multiparty political institutions made it difficult to implement and enforce market transition programs, whether big bang or otherwise.

China's economic success by following a gradualist approach was based upon several elements. First, the top Chinese leadership demonstrated a firm commitment throughout to proceed forward step by step with market reforms and not to permit significant reversals back toward central planning, even when faced with serious economic problems and

\footnotetext{
${ }^{2}$ To be sure, some parts of Eastern Europe, and particularly Hungary, had begun modest experiments with allowing market activity to supplement the socialist planned economy as early as the late 1960s. However, none of these efforts aimed at the eventual dismantling of the centrally planned socialist system the way the Chinese reforms after $1978 \mathrm{did}$ (see Szelenyi 1988). It is unclear, though, whether Deng Xiaoping initially envisioned market reforms going as far as they eventually did under his leadership. The nature of the market institutions China was trying to develop was also not clear initially, and the leadership was definitely not trying to copy Western market institutions wholesale.
}

\footnotetext{
${ }^{3}$ China also had virtually no foreign indebtedness at the beginning of the process of market reforms, a circumstance that perhaps made it easier for Chinese economic decision makers to ignore advice from foreign experts when they felt it did not fit their circumstances and needs.

${ }^{4}$ Since the mid-1990s, most of the countries in the former Soviet bloc have recovered from the big bang-induced economic depression and have started to grow again. However, in the first decade of the new millennium, some had still not regained the economic levels that existed prior to market reforms (see Lin 2007, Popov 2007).
} 
grumbling by some leftist officials and intellectuals about the abandonment of socialism (as in the wake of 1989). This steady determination to push ahead and, as Deng Xiaoping put it, to cross the "river" of market reforms by stepping from stone to stone (despite not having figured out how to complete the journey) signaled to society and to the bureaucratic agents responsible for implementing policy changes that everyone's future depended on making the newly freed market-oriented institutions work and on benefiting from them rather than, say, smothering them at birth. Obviously the fact that, unlike in Eastern Europe, Communist Party rule and state authority did not collapse in China gave credence to these new policy directions.

China also benefited from its particular strategy of implementing partial market reforms. China primarily followed an approach that one scholar (Naughton 1995; see also Naughton 2008a) has called "growing out of the plan." In essence, this involved initially preserving most elements of the planned economy with relatively little change while allowing and actively encouraging the growth of previously prohibited forms of market-based economic activity, such as family farming, private enterprises, private marketing activity, and foreignowned and joint venture firms. These new economic undertakings had to operate and try to succeed in a competitive market environment, and as they did so they relatively quickly began to attract labor power, diligent work efforts, and entrepreneurial energy that had been stifled under the rigid form of socialism that characterized the late-Mao era. ${ }^{5}$

\footnotetext{
${ }^{5}$ As a result of the Cultural Revolution launched in 1966, Mao and his radical colleagues imposed a more restrictive form of socialism than existed in the Soviet Union or Eastern Europe. For example, members of the urban work force worked for fixed wages that did not change for many years, with no bonuses or other material incentives allowed. In rural people's communes, villagers were expected to focus on collectivized labor in the fields and were generally prohibited from engaging in family businesses, making handicrafts for sale, or marketing produce in the cities, and they were even discouraged from selling produce from their private plots in nearby rural markets. One might consider the en-
}

Initially, these market activities were mainly centered in rural areas and in the Special Economic Zones that China created to attract foreign investment after 1979, sequestered economic sectors where they could develop to a considerable degree independently of the then still dominant and mainly urban planned economy. Arguably, the nature of the Chinese economy at the time made it easier to introduce reforms partially there. A country that was still roughly $80 \%$ rural made it possible to experiment with market reforms in agriculture, whereas the economies of the Soviet Union and Eastern Europe were dominated much more by the inefficient and mainly urban firms of the planned economy, where introducing market distribution was more difficult (Woo 1999). ${ }^{6}$ As these market-oriented sectors of China's economy began to show their potential to raise output and incomes (e.g., with rural incomes growing at an unprecedented rate during the first half of the 1980s, lifting millions of farmers out of poverty, and with large infusions of foreign investment arriving to fund nonstate firms as well as joint ventures) they served both as a powerful demonstration of the potential of widely shared gains from market-oriented economic entities and as a growing source of competition that highly inefficient state-owned enterprises would eventually have to face.

Market incentives did not remain confined to the nonstate sector, and here the dual pricing system approved by Chinese authorities by 1985 is important (Byrd 1987, Wu \& Zhao 1987). As an increasing number of goods and services became subject to market prices, even

trepreneurial energy and hard work visible after market reforms were introduced not simply as a manifestation of the centuries-old market and business orientations referred to in the earlier quotation from Rawski, but also as akin to a compressed spring that has finally been released and allowed to bound skyward.

${ }^{6}$ The nature of farming in China also made it easier for a reversion to family farming to succeed. Most farming in China was intensive general field cultivation using simple tools, rather than specialized and mechanized extensive farming. It was much more difficult for a full-time milkmaid or tractor driver in a Russian collective farm to contemplate embarking on family farming than for a Chinese commune member. 
state enterprises could use slack resources to produce for the market once they had met their planned production targets. The fact that market prices were almost always considerably higher than planned prices for the same commodities provided strong incentives for state firms to reorient an increasing share of their activity toward the market. China's dual price structure thus made it possible to avoid the danger of responding to the wrong signals, which was discussed by advocates of the big bang approach, and it also provided increasing pressure on state firms to reorient their priorities from plan to market.

The Chinese reforms also benefited from a recognition that there was a mismatch between the nature of economic institutions inside the plan and China's economic endowments. Despite the fact that China's primary economic resource was inexpensive but disciplined labor, the socialist economy had followed the Soviet path of emphasizing capital-intensive heavy industrial firms, an approach Lin (2007) refers to as "comparative advantage-defying." By allowing new economic activity to spring up outside of the plan, primarily in labor-intensive consumer-goods enterprises and services, China was switching to what Lin terms a "comparative advantage-following" approach to development that contained much more potential for fostering growth.

This strategy of market reforms promoted mainly by growing out of the plan turned out to have another very important consequence that contributed to the success of the Chinese approach. In theory, a comprehensively marketreformed system might have worked better than China's combination of planned and market economies of the 1980s and early 1990s. However, as already noted, the process of trying to get to that goal in Russia and Eastern Europe produced massive disruption and significant loss of income and benefits for much of the population in the interim. As a result, popular resentments about the consequences of dismantling socialist institutions were generated (see Kluegel et al. 1995, Mason \& Kluegel 2000). In contrast, China's dual track strategy of allowing market institutions to develop while temporarily maintaining the planned economy led to something approximating "reform without losers" initially (Lau et al. 2000). In other words, those who participated in the newly released market sectors generally gained in the process, while those remaining dependent on the planned economy were to a considerable extent protected from major losses, creating what economists refer to as a combination of economic efficiency and Pareto-improving distribution. China avoided throwing large numbers of people out of work and into poverty during the initial transition, and popular resentments about the market transition have been substantially lower than in Eastern Europe (Han \& Whyte 2009, Whyte 2010).

To be sure, China has not by any means avoided some of the problems that advocates of the big bang approach pointed out, and official corruption facilitated by China's dual-track approach to reform has been an endemic problem (see Lu 2000, Manion 2004, Yang 2004). However, given the rampant corruption in Russia and some other parts of Eastern Europe (Goldman 2003), it is not clear that the big bang approach is to be preferred even on that score.

Since about 1994, China has entered a new phase in market reforms, with the state vigorously requiring state-owned enterprises to implement market reforms if they are to survive (see Naughton 2008a). Large numbers of employees of the formerly planned sectors of the economy have lost their jobs and benefits since that time, so that the phrase "reform without losers" no longer applies. However, by that point the market-oriented sectors of the economy were not only sufficiently established but increasingly dominant, so that China's future economic success came to depend on the ability of all enterprises, whatever their original institutional form, to operate successfully in a competitive, market-oriented, and global environment. Since about 2000, market exchanges and prices have organized most of the Chinese economy, a situation symbolized by China's accession to the World Trade Organization in 2001. 
To sum up, China did not have either the desire or the realistic option of pursuing a comprehensive, big bang approach to market reforms starting in 1978. The particular strategy adopted of introducing market reforms partially and gradually, while not devoid of predicted problems such as corruption, turned out to have a number of benefits not recognized initially by Western economic experts, whereas comprehensive reforms turned out to be much more difficult to carry out than such experts realized (see also McMillan \& Naughton 1992, Rawski 1999). In retrospect, China appears fortunate not to have listened to experts telling them that their gradual market reform strategy would fail. (For recent analyses on the advantages of gradual reforms, see Kolodko 2000, Popov 2007.)

\section{THE STATE, POLITICAL CHANGE, AND ECONOMIC DEVELOPMENT}

There are multiple paradoxes that involve the relationship between political institutions and economic development in China, only a few of which can be considered here. The most widely discussed question is whether economic development inevitably promotes the democratization of authoritarian systems (Acemoglu \& Robinson 2006, Lipset 1994, Przeworski et al. 2000, Wejnert 2005), and if so whether this is happening in China. Although the past political transitions in Taiwan and South Korea are often cited in support of the growth-democratization causal link in East Asia, there is little sign of this happening yet in China. The Chinese Communist Party (CCP) remains firmly in control and prohibits any potential opposition voices from finding political space, and China's new private business tycoons seem quite content to support Party rule, rather than pressing for political change (Dickson 1997, 2003, 2008). If the effort to succeed in today's global marketplace promotes and requires a dual transition to market distribution and democratization (Centeno 1994), then China again is defying expectations. However, the focus here is on the reverse side of this causal relationship: To what extent have China's political institutions and the role of the state been major contributors to China's recent economic success versus important impediments?

In regard to this question, the existing literature on economic development throws up multiple warning flags about the potential dangers of a major state role in guiding economic development. There is the danger of a predatory state or a state that creates a kleptocracy, as in Goldman's (2003) phrase, the "piratization" of Russia (see also Ding 2000 on illegal asset stripping of state firms in China). There is the danger that even a well-intentioned developmental state will be ill equipped to make good decisions in a rapidly changing and complex global economy. The result may be bad decisions, wasted resources, and disappointing growth or even a national disaster, as in China's Great Leap Forward campaign of 1958-1960, which led to more than 30 million excess deaths and a severe economic depression (Yang 1996; on the general phenomenon, see Scott 1998). There is also the danger of the close relations between government and business evolving into crony capitalism, with financial resources squandered on misguided business ventures of the well connected, while promising small and new ventures of those without state patronage are starved for financing. Some analysts assert that crony capitalism was a primary cause of the Asian financial crisis of 1997 and suggest that the developmental states of Asia are particularly prone to this disease (see Kang 2002, Lim 1998). At the level of the enterprise, the particular problem generated by state encouragement and patronage is a tendency toward "soft budget constraints" (a phrase coined by Kornai 1980, 1992) that allow inefficient firms to survive rather than face the hard budget constraints of unprotected competition in the marketplace.

Even those not persuaded that the multiple perils of state guidance of the economy make a minimalist role of the state necessary recognize the difficulty of determining what makes for a positive versus a negative government role. For example, Evans (1995) recommends a relationship of "embedded autonomy" between the 
state and business elites, but discusses how difficult it is to find and maintain the desired balance implied by this formula. The difficulties became even more apparent in 1997 when South Korea, heretofore lauded as a success story for striking the right balance, was badly affected by the Asian financial crisis and was described by critics as a clear case of the dangers of crony capitalism (e.g., Kang 2002).

In any case, one would have thought that China was particularly ill prepared to become a positive model of a successful developmental state. This was, after all, a society with a recent history of persistent and even monumental mismanagement of the economy (see Naughton 1991). Furthermore, as noted at the outset of this essay, China had in 1978 a political system led by lifelong communist apparatchiks who presided over a bureaucracy largely composed of poorly educated but politically loyal and obedient officials whose career success did not depend substantially on economic expertise or performance. In other words, this was hardly the highly trained technocracy that is widely given credit for the success of other East Asian economies (Amsden 1989, Johnson 1982, Wade 1990), not to mention the Weberian rational state that has been conducive to economic growth more generally around the world (Chibber 2002, Evans \& Rauch 1999).

Nonetheless, the introduction of market reforms and guidance of the economy in China since 1978 have clearly been primarily topdown, state-driven processes. ${ }^{7}$ How and why has the Chinese economy been able to be so successful despite developing under the very visible and often heavy hand of the state? Part of the explanation is that China had models close at hand in East Asia of developmental states that

\footnotetext{
${ }^{7}$ The primary exception to this generalization is an important one. The rural reforms that in some sense launched the reform process were initiated by the relatively spontaneous decollectivization efforts of Chinese farmers in depressed locales, efforts that were only gradually and at first somewhat reluctantly approved by central authorities. Subsequently, the government's attitude changed, and decollectivization was made virtually mandatory throughout rural China (see the discussion in Yang 1996, Zweig 1997).
}

successfully guided market-oriented development, models that could be studied and adapted to Chinese conditions. The world had changed drastically since the 1950s, when China had looked to the Soviet Union as a model of successful socialist development and had adapted Soviet institutions and policies to Chinese conditions (and when Japan and the East Asian tigers had not yet begun their dramatic rise). By the 1980s, the planned socialist model was recognized as a dead end, but China could turn to East Asian neighbors for models of how to organize a high-growth, market-oriented economy with a potential for rapidly improving the living standards of the population. China was trying to repeat the strategy used earlier by the Asian tigers in following the example of Japan, a process referred to as the "flying geese" approach to development (Sugihara 2003, Vogel 1991).

This borrowing is usually thought of primarily in terms of China shifting from capitalintensive autarchic development to more laborintensive production of consumer goods for export. However, equally important were the major structural changes in the political and administrative system. The latter changes belie the common perception that China's strategy involved reforming economic institutions while leaving its political system unchanged. The overhaul of the political system involved a large number of elements that have had a very substantial cumulative effect, only a few of which can be discussed here.

One important change was a rapid and thorough transformation in the personnel recruitment, promotion, and incentive practices at all levels of the party and state bureaucracy. The unsuitability of a large portion of the existing bureaucratic personnel to manage firms and governments and promote market-oriented development was recognized, and a dramatic shifting of gears occurred as younger and better educated people were recruited to replace poorly educated but politically loyal officials at all levels (see Eldersveld \& Shen 2001, Li \& White 1990). The People's Republic of China implemented, for the first time, a mandatory 
retirement system for officials, clearing the way for younger officials to rise (Manion 1993). The Chinese state was rapidly transformed from a "virtuocracy" (Shirk 1984) to a meritocracy, with even the top party leadership now composed mainly of college educated technocrats, particularly alumni of China's prestigious Tsinghua engineering university ( $\mathrm{Li}$ 1994). China also repudiated the late Mao-era prohibition on material incentives and adopted a quantitative system for assessing and rewarding local officials, using economic development success as the primary indicator for determining compensation. Those leaders of localities or enterprises that performed well economically were given sizeable monetary rewards in recognition of this success (Naughton 2008b, Oi 1992).

Another important component of the reforms of the state administrative system was the combination of administrative decentralization and altered financial regulations that fundamentally changed the nature of the state's administration of the economy. Large numbers of formerly centrally administered state enterprises were transferred to provincial and lower levels of administration (building on decentralization waves of the Mao era), and, starting in 1980, subordinate governments entered contractual agreements with higher levels specifying the amount of revenue the lower level had to turn over to the next higher level. Remaining and additional budgeted revenue and any new extrabudgetary funds generated by the lower levels did not have to be remitted to higher levels as had been the case before, but could be used locally to stimulate economic development, supply public goods, and for other purposes. Similar arrangements were adopted for production enterprises in their relations with their supervising levels of government, and in addition enterprise responsibilities for pensions and other welfare benefits for their employees and retirees began to be taken over by pooled funds supervised by local governments in a move designed to allow enterprises to concentrate on their core economic activities. Although these arrangements were not enshrined in any formal changes in constitutional arrangements, they quickly acquired a durability that reassured lower levels of government and the enterprises they supervised that they were safe from demands from higher levels for increases in financial "contributions" (see Montinola et al. 1996, Naughton 2008b, Oi 1992). Montinola and colleagues (1996) characterize the altered administrative system as "market-preserving federalism," although "market-preserving decentralization" might be more accurate, given the absence of any formal federal structure of the Chinese political system.

As a consequence of these changes, local governments and enterprises were provided with a relatively secure set of administrative and fiscal arrangements that enabled them to concentrate on pursuing new market opportunities and developing their economies with assurance that, if they were successful, most of the increased revenue generated could be used locally to generate more of the same, not to mention financial rewards for those in charge. Firms and local governments also knew that if they lost money they would no longer be bailed out by higher levels, thus forcing them to face market competition in a structure imposing relatively hard budget constraints. Localities and enterprises that were relatively slow to pursue new market opportunities could readily observe how they were falling behind the prosperity of their neighbors, and the resulting envy stimulated increased efforts to copy the successful market-oriented policies and institutions of front-runners (Vogel 1989). The combination of financial rewards for local officials for success in economic development and increased public revenues generated by local firms provided powerful incentives for quickly adopting practices suited to operating in the new market environment (Walder 1995). The hectic market competition among local firms and governments unleashed by these changes was a fundamental source of China's new economic dynamism.

A particularly dramatic manifestation of the impact of the changed administrative system involves the growth and changing 
organizational forms of China's township and village enterprises (TVEs). In the late Mao era, rural industry was burdened by restrictions and generally allowed to produce only tools, cement, and other products to serve the needs of the local community, and as a consequence there were relatively few workers employed in rural factories nationwide prior to 1978 (see Perkins 1977). The combination of altered administrative and financial systems with new market opportunities-to produce goods for the long-deprived domestic market, to export products to overseas markets, to attract investment funds from Hong Kong and other outside sources, etc.-stimulated local governments to scout out new opportunities and establish local factories to meet those opportunities. The local factories were major contributors to growing out of the plan (Naughton 1995), and initially they were mostly run and financed by local governments, an arrangement that one researcher terms "local state corporatism" (Oi 1992, 1995). The dramatic rise of TVEs resulted in the employment of over 100 million workers by the early 1990s and a situation in which close to $30 \%$ of China's total industrial output was produced by this sector (Naughton 2007). The dynamic growth and increasing national importance of the TVE sector in the 1980s and 1990s belie the expectation that government-run firms are unlikely to produce robust economic development.

However, as the competitive field of TVE production became more crowded, and as some local assessments of market opportunities failed to pan out, a rising portion of TVEs began to suffer financial losses, losses for which their supervising local governments were responsible. Those governments recognized the risks to which they had exposed themselves in their rush to benefit from market reforms, and relatively quickly they adapted to the situation by pushing privatization of TVEs, as well as by closing unsuccessful firms that no private manager would agree to take on (Oi 1999, Ruf 1999). By the mid-1990s the great bulk of TVEs had been transformed into private enterprises, with their owners responsible for profits and losses, but with local governments still benefiting in the former instance from receiving their agreed share of firm profits. ${ }^{8}$

There is not space here to discuss many other aspects of the state's role in guiding China's economy. However, one point should be stressed in relation to the previous literature and the example of other East Asian economies. China has placed less emphasis than other East Asian developmental states on the central government's role in formulating industrial policy, picking winners in emerging new technologies, or protecting favored enterprises, in the manner of MITI in Japan (Johnson 1982) and state support for chaebol in South Korea (Amsden 1989, Lie 1998). Rather, as noted earlier, much of the initial economic growth occurred via the efforts of private, TVE, foreign, and other firms to grow out of the plan. The role of the state in pursuing this strategy was mainly to remove regulatory obstacles and establish institutions to provide positive market incentives and foster competition to facilitate the growth and success of these new firms (Naughton 1995). So, for example, a tremendous effort over the years has been devoted by the state to attracting foreign direct investment-through establishing Special Economic Zones with reduced taxes and other inducements, through rapidly developing legislation governing and protecting foreign investment and repatriation of profits overseas on attractive terms, and in general through trying to enhance the business climate and overcome barriers to further development of markets. (On industrial policy in East Asia in general, see also Amsden 2008, Amsden \& Chu 2003, Noland \& Pack 2003).

China's difference from earlier East Asian tigers in this respect is only relative, given

\footnotetext{
${ }^{8}$ Since the mid-1990s, the TVE sector has not been growing as rapidly as before. In recent years, employment has leveled off at around 140 million workers in this sector (Naughton 2007), and TVEs now play a less prominent role in China's economic growth. One additional reason for TVE privatization was the 1994 fiscal reforms that allowed the central government to recapture a larger share of locally generated revenues, thus making TVEs less attractive cash cows for local governments.
} 
that the central government has clearly favored and promoted some industries and technologies (e.g., military-related industries, automobiles). And where there has been direct state support of specific economic sectors and activities, endemic problems are visible, such as residual crony capitalism tendencies for most state bank loans to continue to be channeled to large state enterprises and used to support investments of often questionable value and profitability. [See the critique in Lardy (1998), Nee \& Opper (2007), Wu (2006); however, several researchers, including Guthrie (1998, 1999) and Keister (2002), contend that these tendencies are declining over time].

In sum, the Chinese party/state has been in the driver's seat in directing the development process in China. However, the approach taken by Deng Xiaoping and subsequent reformers has been to use the power of the state primarily to promote markets, foster competition, and stimulate market-oriented incentives, rather than to try to pick winners and favor investment in those firms with the closest ties to the state. To promote market-oriented development, fundamental changes have occurred in how the Chinese state is organized and operates, although pressures for democratization have been strongly and so far successfully resisted. Although there have also been recurring problems with corruption, crony capitalism, and other predicted costs of heavy state involvement, on balance the Chinese experience since 1978 is mostly an example of a very successful developmental state.

\section{GETTING THE INSTITUTIONS RIGHT?}

The fourth and final paradox to be discussed here is the widespread belief that a key, or perhaps even the key, to successful economic development is "getting the institutions right" (see Rodrik 2007, chapter 6). There is a rich literature devoted to this topic, ranging from Adam Smith and others down to Ronald Coase (1988, 1992), Douglass North (1990, 1995; North \& Thomas 1973), and many others in recent times. Why does this literature say it is important to get the institutions right in order to promote economic development? Although much could be said in answer to this question, the bottom line is generally the argument that having the wrong institutions will not provide optimal incentives to individuals, firms, financial institutions, and even nations, and as a result economic growth will not be stimulated or will be anemic at best. Certainly there is much to be said for this argument, and China's experience in the era of planned socialism provides copious examples of the economic damage and waste caused by bad institutions and the poor incentives they provided (see again Naughton 1991).

However, there is continuing debate about what the right institutions are. One influential listing (Williamson 1990) was termed the "Washington consensus" because it reflected the neoliberal economic thinking prevalent in the World Bank and the United States government at the time. The consensus consisted of a list of ten recommended economic policies/institutions: fiscal discipline, progrowth expenditure priorities, tax reform, liberalizing interest rates, a competitive exchange rate, trade liberalization, liberalization toward inward foreign direct investment, privatization, deregulation, and private property rights.

However, recent assessments (Rodrik 2008, Stiglitz 2008) argue that the countries that went furthest in implementing Washington consensus reforms, primarily countries in Latin America, had worse economic records after these reforms than prior to them and also worse records than countries that did not follow the Washington consensus approach. This outcome throws into serious question the idea that such a one-size-fits-all set of institutional arrangements can lead to growth in every country, not to mention the notion that neoliberal approaches to economic management are now universally triumphant (Fukuyama 1992). ${ }^{9}$

\footnotetext{
${ }^{9}$ For a discussion of the Washington consensus list, see Williamson 1990, 2008. For a more general discussion and critique of the Washington consensus, see Serra \& Stiglitz 2008. In his retrospective essay on the term he coined,
} 
Despite such doubts, there is much more agreement on the importance of secure private property rights as a vital prerequisite for economic development. As summarized recently by Acemoglu et al. (2005, p. 395; see also de Soto 2000), good economic institutions are defined "as those that provide security of property rights and relatively equal access to economic resources to a broad cross-section of society." However, the problem when this idea is applied to the Chinese economy since 1978 is obvious. China has certainly been ardent in pursuing some items on the Washington consensus list, such as a progrowth investment policy and liberalization toward inward foreign direct investment. However, in other respects, and particularly in regard to the key issue of private property rights, the Chinese have persisted in getting the institutions wrong, and yet the economy has continued to boom. How can this success be explained?

Before attempting to address this question, a brief discussion of the nature of property rights in China today is in order (for fuller discussion, see Oi \& Walder 1999). There are multiple other domains in which China also departs from lists of the right institutions to promote development (such as by state management of currency exchange rates), but given the key place in orthodox economic thought of private property rights, we set those other domains aside here. The situation of property rights differs in rural versus urban China. In the countryside, decollectivization of agriculture in the early 1980s restored family farming, but families did not receive private property rights to the land they cultivated, which remains the collective property of the villages in which they live. Instead the land was divided up and leased out to local families, with leases since 1994 extended to 30 years. The national policy

Williamson (2008) contends that Stiglitz and others misinterpreted his list as neoliberal market fundamentalism and that Latin American countries that performed poorly had actually failed to adopt key provisions in his list. He also acknowledges that his list omitted other important elements that can foster development, such as a priority on social equity. is that the leased plots should not be readjusted during the lifetime of the contract, with leases inheritable by subsequent generations. One might see the government's rural land policy as attempting to promote something close to secure private property rights, but without taking the final step of providing full legal title in perpetuity. However, the complication in reality is that in many villages in China local leaders and farmers defy central policy by periodically reallocating village land-particularly to compensate for changes in family size and labor power attributable to births, deaths, marriages, and out-migration, but also to serve other goals, such as sanctioning compliance with other policies, such as family planning (see Brandt et al. 2002, Prosterman 2001). So, in fact, in many villages Chinese farmers have no guarantee that they will continue to be farming next year all the plots they farm today, although existing research suggests that a majority of farmers favor rather than oppose these periodic reallocations (see Kung \& Liu 1997).

However, there is another growing threat to the land rights of China's farmers that is much more contentious. Rural officials in increasing numbers of villages are entering into business deals with outside developers to lease out village land for use in constructing housing estates, shopping malls, or factories, with farmers launching protests when they feel they have not been properly consulted and compensated in these deals (O’Brien \& Li 2006).

In sum, China's agricultural land has still not been fully privatized even 30 years after the launching of market reforms. ${ }^{10}$ Full private ownership is, however, present in other spheres in the rural economy, including housing and family-run and privatized TVE businesses,

\footnotetext{
${ }^{10}$ In October 2008, an important meeting of the CCP took place devoted to rural land tenure issues. At that meeting, land use contracts were extended beyond 30 years (perhaps even indefinitely) and markets for the sale and exchange of such rights were authorized, although still without providing China's farmers with full legal title to the land they till. It remains to be seen whether the conclusion offered here will continue to be the case, or whether further steps toward privatization of agricultural land will be taken and implemented.
} 
although with the usual caveat about the relative weakness of Chinese courts and other legal institutions in providing protection to property owners.

In the cities, the situation is more complicated. Land remains state property, but again available for long-term lease for housing, business, and other purposes. China's dual track approach to reform initially rejected privatization of state-owned economic enterprises that were the legacy of the era of planned socialism, unlike the strategy in the former Soviet Union and Eastern Europe. However, private enterprises could be established from the 1980s onward, and foreign enterprises were welcomed into China and able to operate not only as joint ventures, but also as majority foreignowned firms, in some cases even with 100\% equity stakes. However, initially in the 1980 s there were sharp limits on how many employees could be hired by a domestic private firm, and legislation to fully proclaim the rights to private property in such businesses was not adopted in China until 2007. Despite these restrictions and uncertainties, China's private and foreign-owned sectors of the economy grew rapidly over the years, while the share of output and employment associated with state firms declined. ${ }^{11}$

As a result of the more extensive set of reforms launched in 1994, China's state-owned enterprises eventually began to experience at least quasi privatization, but this process still leaves the state in a dominant position in most instances. In some cases, faltering state-owned enterprises were merged or sold to private individuals or companies or even closed down, rather than being continually propped up with bank loans. Stock markets were established in Shanghai and Shenzhen starting in 1990, enabling individuals, other firms, or in some cases

\footnotetext{
${ }^{11}$ The numbers of workers and employees in state firms declined from a peak of around 110 million in the mid-1990s to only a little over 60 million in 2007 (according to China's online national statistics, available at http://chinadataonline.org.ezp-prod1.hul.harvard.edu/ $\mathrm{member} / \mathrm{macroy} / \mathrm{macroytshow} \cdot \mathbf{a s p}$ ? $\operatorname{code}=\mathrm{A0202}$ ).
}

even foreign individuals and firms to buy shares and establish a substantial ownership stake in many Chinese state companies. However, generally only certain types of shares are freely traded, while others, generally a majority stake, remain in the hands of the state. So in urban state enterprises as well as in agricultural land, full privatization and the establishment of secure private property rights are still being resisted and restricted.

So if in regard to the issue of private property rights China has persisted in getting the institutions wrong, why is economic growth in China showing so few signs of the economic harm that the experts say this should cause? Several circumstances may help explain this paradox. First, although there have been and remain restrictions on the realms to which private property rights apply, in general the state has moved consistently in the direction of further expansion of private enterprise and ownership, rather than backtracking and launching renationalization of private assets as might have been feared. In fact, as noted earlier, in the case of agricultural land the state has tried to foster changes in the direction of firmer property rights and has been thwarted. So in some ways the record of state actions in China after 1978 displays a commitment to markets and proper incentives that would presumably please Adam Smith, despite the fact that these are the acts of lifelong communist bureaucrats. The Chinese case indicates that viewing economic guidance as being provided by markets versus by governments can be highly misleading, given that a developmental state can play a key role in fostering market distribution and competition.

A second consideration is that fairly quickly the prospects of dramatic profits and personal enrichment through private business and the lure of profits to be made by foreign firms in the vast China market reassured potential entrepreneurs and investors that they could recoup their investments in only a few years. This was in contrast with the decades of stagnant incomes of the Mao period. Thus, individuals and foreign firms found the risks of long-term threats to their property stake worth 
taking. A final consideration concerns relative expectations. If you have been living in a strict socialist economy in which you have no productive property from which you can profit at all, even the fuzzy, imperfect, and perhaps temporary property claims established as a result of the reforms may provide all the incentive you need to use that property for personal gain in a highly energetic fashion (Oi 1992; see also the discussion of Chinese "fuzzy property rights" in Ho 2001, Sanders \& Chen 2005).

These considerations suggest that the attention focused on secure private property rights by most institutionalist theorists of development is misplaced. Having secure rights in my property may do little to foster development if there is no structure of opportunities and incentives in the larger society to induce me to use my property in an increasingly productive way, or if a few established economic actors monopolize available opportunities. On the other hand, a sufficiently conducive structure of opportunities and incentives throughout society and intense competition to gain access to such opportunities may induce me to work harder, innovate, take risks, and be more entrepreneurial in general, even if I have some uncertainty about how secure my private property rights are. Walder \& Oi (1999) refer to this situation as the "utility of suboptimal solutions." (Huang 2008 refers to this syndrome of improved but still insecure property rights as "directional liberalism.") If this reasoning is accepted, then private property rights are not so important per se, but only as one institutionalized option (although a common and often very powerful one) for fostering positive development incentives and opportunities for individuals, families, and firms. In short, even though China has not provided secure private property rights, the overall improvements in competition, opportunities, and incentives that are intended to foster hard work, entrepreneurship, and innovation are sufficiently strong that they provide economic dynamism in China that secure private property rights alone could not provide (see a similar conclusion in Rodrik 2007).

\section{CONCLUSIONS}

In this review, I have considered four paradoxes that lead one to expect that China after 1978 could not be very successful at economic development. In each case, I have tried to explain how and why China's economic performance contradicts these expectations. Explaining why China did not fail at development after 1978 is not the same as explaining why she succeeded, although parts of the story are embedded in previous sections of this review. Although debunking four kinds of conventional wisdom about development is the main purpose of this article, in closing I briefly sketch, but do not elaborate here, some of the additional contributing factors to China's success. (These points are drawn from a related paper, Whyte 2007, in which they are developed and discussed at greater length).

China's traditional cultural legacy provided fertile ground for recent economic development and market competition in a number of respects:

1. centuries of familiarity with a social order with great inequality but few barriers to social mobility, and with high actual geographic and social mobility rates;

2. strong family traditions of emphasizing education (but primarily for sons) and the pursuit of economic betterment for the family;

3. centuries of familiarity with marketing, private business activity, forming partnerships, commercial contracts, and other practices of a modern market economy;

4. the availability of many more natural resources than are possessed by other East Asian states (although not enough to encourage reliance on raw material exports as a growth strategy);

5. a large population size that could provide the basis for robust domestic market demand once disposable incomes increased, thus making reliance on production for export less central to economic growth over time.

Despite monumental errors, China's years under centrally planned socialism provided 
some positive foundations for subsequent economic growth as well, including the following:

1. political stability and a strong state that could be converted into a successful developmental state, although only after considerable retooling;

2. the absence of entrenched economic elites who could use their wealth to capture most benefits of growth or to block or distort economic development initiatives;

3. an impressive increase in heavy industrial, transportation, and other economic infrastructure as well as in the number of Chinese trained to work with modern industrial machinery;

4. major improvements in the human capital of the Chinese population in terms of educational attainment (including a strong emphasis on technical, scientific, and engineering fields in line with the Soviet model) and in the health and life spans of the population, making Chinese workers and specialists attractive in the eyes of potential foreign and domestic employers;

5. substantial improvement in the human capital and economic contributions of women (again in line with the Soviet model);

6. exposure of most of the population, including rural residents, to the routines and discipline of bureaucratic work organizations;

7. a demographic dividend produced by rapid state-induced fertility decline starting in 1970, prior to the one-child policy, ${ }^{12}$ sharply increasing the size of the labor force relative to the total population;

\footnotetext{
${ }^{12}$ Contrary to popular belief, most of China's fertility decline preceded the launching of the one-child policy in 1979. About $80 \%$ of China's fertility decline (from a total fertility rate of 5.8 in 1970 to only about 1.6 today)occurred as a result of the already highly coercive family planning policy of the 1970s, which was launched with Mao Zedong's approval (see Wang \& Mason 2005, Greenhalgh \& Winckler 2005). The one-child policy was launched partly to keep fertility rates from rising again, but also to try to drive fertility rates below replacement level in order to pursue an extraordinary goal of
}

8. the absence of substantial foreign debts, providing China with much more flexibility in designing economic policies than most developing countries have;

9. finally, the fact that socialism lasted only a generation (1955-1978), unlike in the Soviet Union, so that memories and experiences of operating in a market society were still present in the population and could be revived.

At the same time, the legacy of economic mismanagement, distortions, and the rigidity of the Chinese socialist system left major problems that had to be overcome after 1978. However, several of these had the potential to provide positive contributions to China's subsequent development in a reaction formation fashion:

1. having a large portion of the population, particularly the roughly $80 \%$ still residing in rural areas, who had been consigned to almost feudal subjugation in the planned economy and who were thus eager to take advantage of any new market opportunities;

2. an extraordinary accumulation of consumer frustrations, typical of but perhaps even more extreme than in other planned economies, producing strong domestic demand for goods and services that socialism had not provided, thus helping to create strong market incentives for TVEs and other new but initially not very efficient market-oriented businesses;

3. a substantial discrediting of the symbols, slogans, and institutions of socialism produced by the chaos of the Cultural Revolution (1966-1976), making it easier for Chinese at all levels to embrace previously denounced market practices and symbols.

Then, in terms of the post-1978 changes and strategy, in addition to the thorough overhauling of the state administrative system and the fundamental reorientation from a Soviet-style

eventually reducing China's population below its 1979 level (Greenhalgh 1995). 
planned economy to a version of an East Asian export-oriented economy, as discussed earlier in this review, there were a number of other circumstances that worked in China's favor, including the following:

1. fortuitous timing that allowed China to fill the gap in the global manufacturing supply chain that opened because of rising labor costs in Japan and in the East Asian tigers, enabling China to become the next flying goose to line up to fill the shelves of Wal-Mart and other consumer emporia in the West;

2. the similarly fortuitous timing of a Cold War-induced change in American foreign policy, from isolating to embracing China as a counterweight to the Soviet Union, thus opening up the United States to Chinese products and students while providing technology, teachers, and other inputs to help fuel China's development;

3. the availability of a substantial Chinese diaspora of wealthy capitalists in Hong Kong, Taiwan, and overseas who were motivated to invest in China for emotional as well as economic reasons and to share their expertise in penetrating foreign markets.

This list is selective rather than exhaustive, but it is intended to convey the complexity of the contingencies and factors that have contributed to China's extraordinary economic boom over the past three decades. China's economic success was unanticipated, and it depended on a large number of factors, changes, and contingencies. Some of those, such as the demographic dividend and China's low labor costs, are now becoming less operative, with Vietnam and other even poorer countries only too willing to take business away from China. At the same time, a variety of other factors could arise to threaten China's economic progress, such as a weakening of economic demand in the West, environmental crises or political instability in China, and mismanagement of the remaining state sectors of the economy. The onset of the global financial meltdown late in 2008 posed a severe test of the ability of China's leaders to sustain the extraordinary growth record of the past three decades. One has only to look at Japan since 1990 to see how an East Asian economic miracle can cease to be very miraculous. Although China's leaders will do everything they can to try to keep their economy growing rapidly enough to generate robust increases in employment and living standards, not to mention continued popular acceptance of CCP rule, it is by no means obvious that China's extraordinary boom for the last three decades can be sustained in the future.

In terms of generalizations for economic development prospects elsewhere, the implications of China's economic boom are mixed. The clear evidence that China provides that there is no single development strategy or set of institutions that have to be adopted everywhere to foster development should be encouraging. Rather than copy the "best practice" used elsewhere, it would be more productive to conduct a realistic analysis of the current resources and capabilities in any particular poor country and study how these relate to the prevailing constraints and opportunities in the global economy. Such an analysis will determine how to overcome the primary obstacles to growth in that country and how to take maximum advantage of current opportunities (see Hausmann et al. 2008, Lin 2007). But this conclusion also means that it will not be very productive to study the Chinese model in order to figure out how to replicate China's success in country X. The factors that have made China so unexpectedly successful at economic development since 1978 are multiple and complex, and many of them turn on deep-rooted historical characteristics or fortuitous timing that cannot readily be duplicated. This conclusion may be more discouraging for other developing societies. They can take heart from the fact that it is still possible for a poor country to change its economic fate and dramatically improve its economic performance, but each must find its own path to do so, rather than simply copy China. 


\section{DISCLOSURE STATEMENT}

The author is not aware of any affiliations, memberships, funding, or financial holdings that might be perceived as affecting the objectivity of this review.

\section{ACKNOWLEDGMENTS}

I appreciate comments received on this and a related paper from Gary Jefferson, Nicholas Lardy, Jean Oi, Dwight Perkins, Thomas Rawski, Dani Rodrik, Ezra Vogel, and Andrew Walder, none of whom is responsible for any remaining shortcomings.

\section{LITERATURE CITED}

Acemoglu D, Johnson S, Robinson J. 2005. Institutions as a fundamental cause of long-run growth. In Handbook of Economic Growth, ed. P Aghion, S Durlauf, 1:385-472. New York: Elsevier

Acemoglu D, Robinson J. 2006. Economic Origins of Dictatorship and Democracy. New York: Cambridge Univ. Press

Amsden AH. 1989. Asia's Next Giant: South Korea and Late Industrialization. New York: Oxford Univ. Press Amsden AH. 2008. The wild ones: industrial policy in the developing world. See Serra \& Stiglitz 2008, pp. $95-119$

Amsden AH, Chu W-W. 2003. Beyond Late Development: Taiwan's Upgrading Policies. Cambridge, MA: MIT Press

Arkush D. 1984. If a man works hard, the land will not be lazy: entrepreneurial values in North China peasant proverbs. Mod. China 10:461-79

Bellah R. 1957. Tokugawa Religion: The Values of Pre-Industrial fapan. Glencoe, IL: Free Press

Brandt L, Huang J, Li G, Rozelle S. 2002. Land rights in China: facts, fictions, and issues. China 7. 47:67-97 Byrd WA. 1987. The impact of the two-tier plan/market system in Chinese industry. F. Comp. Econ. 11:295-308

Centeno M. 1994. Between rocky democracies and hard markets: dilemmas of the double transition. Annu. Rev. Sociol. 20:125-47

Chibber V. 2002. Bureaucratic rationality and the developmental state. Am. F. Sociol. 107:951-89

Clark G. 2007. A Farewell to Alms: A Brief Economic History of the World. Princeton, NJ: Princeton Univ. Press

Coase R. 1988. The Firm, the Market, and the Law. Chicago: Univ. Chicago Press

Coase R. 1992. The institutional structure of production. Am. Econ. Rev. 82:713-19

Coble P. 1980. The Shanghai Capitalists and the Nationalist Government, 1927-1937. Cambridge, MA: Harvard Univ. Press

De Soto H. 2000. The Mystery of Capital: Why Capitalism Triumphs in the West and Fails Everywhere Else. New York: Basic Books

Dickson B. 1997. Democratization in China and Taiwan: The Adaptability of Leninist Parties. New York: Oxford Univ. Press

Dickson B. 2003. Red Capitalists in China. New York: Cambridge Univ. Press

Dickson B. 2008. Wealth and Power in Contemporary China: The Communist Party's Embrace of the Private Sector. New York: Cambridge Univ. Press

Ding XL. 2000. The illicit asset stripping of Chinese state firms. China 7. 43:1-28

Eldersveld S, Shen MM. 2001. Support for Political and Economic Change in the China Countryside. Lanham, MD: Lexington

Elvin M. 1973. The Pattern of the Chinese Past. Stanford, CA: Stanford Univ. Press

Evans P. 1995. Embedded Autonomy: States and Industrial Transformation. Princeton, NJ: Princeton Univ. Press

Evans P, Rauch J. 1999. Bureaucracy and growth: a cross-national analysis of the effects of "Weberian" state structures on economic growth. Am. Sociol. Rev. 64:748-65

Feuerwerker A. 1977. Economic Trends in the Republic of Cbina, 1912-1949. Ann Arbor: Univ. Mich. Cent. Chin. Stud.

Fukuyama F. 1992. The End of History and the Last Man. New York: Free Press 
Gates H. 1996. China's Motor: A Thousand Years of Petty Capitalism. Ithaca, NY: Cornell Univ. Press

Goldman M. 2003. The Piratization of Russia: Russian Reform Goes Awry. New York: Routledge

Greenhalgh S. 1995. Missile science, population science: the origins of China's one-child policy. China Q. 182:253-76

Greenhalgh S, Winckler E. 2005. Governing China's Population: From Leninist to Neoliberal Biopolitics. Stanford, CA: Stanford Univ. Press

Guthrie D. 1998. The declining significance of guanxi in China's economic transition. China Q. 154:254-82

Guthrie D. 1999. Dragon in a Three-Piece Suit: The Emergence of Capitalism in China. Princeton, NJ: Princeton Univ. Press

Han CP, Whyte MK. 2009. The social contours of distributive injustice feelings in contemporary China. In Creating Wealth and Poverty in Post-Socialist China, ed. DS Davis, F Wang, pp. 193-212. Stanford, CA: Stanford Univ. Press

Harrell S. 1985. Why do the Chinese work so hard? Reflections on an entrepreneurial ethic. Mod. China 11:203-26

Harrison L, Huntington S, eds. 2000. Culture Matters: How Values Shape Human Progress. New York: Basic Books

Hausmann R, Rodrik D, Velasco A. 2008. Growth diagnostics. See Serra \& Stiglitz 2008, pp. 324-55

Ho P. 2001. Who owns China's land? Policies, property rights, and deliberate institutional ambiguity. China Q. 166:394-421

Howe C. 1978. China's Economy: A Basic Guide. New York: Basic Books

Huang Y. 2008. Capitalism with Chinese Characteristics: Entrepreneurship and the State. New York: Cambridge Univ. Press

Johnson C. 1982. MITI and the Fapanese Economic Miracle. Stanford, CA: Stanford Univ. Press

Kang D. 2002. Crony Capitalism: Corruption and Development in South Korea and the Philippines. New York: Cambridge Univ. Press

Keister LA. 2002. Guanxi in business groups: social ties and the formation of economic relations. In Social Connections in China: Institutions, Culture, and the Changing Nature of Guanxi, ed. TB Gold, D Guthrie, D Wank, pp. 77-96. New York: Cambridge Univ. Press

Kluegel J, Mason D, Wegener B, eds. 1995. Social fustice and Political Change. New York: de Gruyter

Kolodko GW. 2000. From Shock to Therapy: Political Economy of Postsocialist Transformation. New York: Oxford Univ. Press

Kornai J. 1980. Economics of Shortage. New York: Elsevier

Kornai J. 1990. The Road to a Free Economy: Shifting from a Socialist System. New York: Norton

Kornai J. 1992. The Socialist System: The Political Economy of Communism. Princeton, NJ: Princeton Univ. Press

Kung J, Liu S. 1997. Farmers' preferences regarding ownership and land tenure in post-Mao China: unexpected evidence from eight counties. China 7. 38:33-63

Landes D. 2003. The Unbound Prometheus: Technological Change and Industrial Development in Western Europe from 1750 to the Present. Cambridge, UK: Cambridge Univ. Press. 2nd ed.

Lardy N. 1998. China's Unfinished Economic Revolution. Washington, DC: Brookings Inst.

Lau L, Qian Y, Roland G. 2000. Reform without losers: an interpretation of China's dual-track approach to transition. F. Polit. Econ. 108:120-43

Levy M Jr. 1955. Contrasting factors in the modernization of China and Japan. In Economic Growth: Brazil, India, Japan, ed. S Kuznets, W Moore, JJ Spengler, pp. 496-536. Durham, NC: Duke Univ. Press

Li C. 1994. University networks and the rise of Qinghua graduates in China's leadership. Aust. F. Chin. Aff. 32:1-30

Li C, White L. 1990. Elite transformation and modern change in Mainland China and Taiwan: empirical data and the theory of technocracy. China Q. 121:1-35

Lie J. 1998. Han Unbound: The Political Economy of South Korea. Stanford, CA: Stanford Univ. Press

Lim L. 1998. Whose "model" failed? Implications of the Asian economic crisis. Wash. Q. 21:25-36

Lin JY. 2007. Development and Transition: Idea, Strategy, and Viability. Draft Pap. Marshall Lect., Cambridge Univ., UK

Lipset SM. 1994. The social requisites of democracy revisited. Am. Sociol. Rev. 59:1-22 
Lu XB. 2000. Cadres and Corruption: The Organizational Involution of the Chinese Communist Party. Stanford, CA: Stanford Univ. Press

Manion M. 1993. Retirement of Revolutionaries in China. Princeton, NJ: Princeton Univ. Press

Manion M. 2004. Corruption by Design: Building Clean Government in Mainland Cbina and Hong Kong. Cambridge, MA: Harvard Univ. Press

Mason D, Kluegel J, eds. 2000. Marketing Democracy: Changing Opinion about Inequality and Politics in East Central Europe. Lanham, MD: Rowman \& Littlefield

McMillan J, Naughton B. 1992. How to reform a planned economy: lessons from China. Oxf. Rev. Econ. Policy 8:130-43

Montinola G, Qian Y, Weingast B. 1996. Federalism, Chinese style: the political basis for economic success. World Polit. 48:50-91

Murphy K, Shleifer A, Vishny RW. 1992. The transition to a market economy: pitfalls of partial reform. Q. F. Econ. 26:618-34

Naughton B. 1991. The pattern and legacy of economic growth in the Mao era. In Perspectives on Modern China, ed. J Kallgren, K Lieberthal, R MacFarquhar, F Wakeman, pp. 226-54. Armonk, NY: M.E. Sharpe

Naughton B. 1995. Growing Out of the Plan: Chinese Economic Reform, 1978-1993. New York: Cambridge Univ. Press

Naughton B. 2007. The Chinese Economy: Transitions and Growth. Cambridge, MA: MIT Press

Naughton B. 2008a. A political economy of China's economic transition. In China's Great Economic Transformation, ed. L Brandt, TG Rawski, pp. 91-135. New York: Cambridge Univ. Press

Naughton B. 2008b. Restructuring the authoritarian hierarchy: incentives and job design in China's state sector. Presented at Adaptive Authoritarianism: China's Party-State Resilience in Historical Perspective, Harvard Univ., Cambridge, MA

Nee V, Opper S. 2007. On politicized capitalism. In On Capitalism, ed. V Nee, R Swedberg, pp. 93-127. Stanford, CA: Stanford Univ. Press

Noland M, Pack H. 2003. Industrial Policy in an Era of Globalization: Lessons from Asia. Washington, DC: Inst. Int. Econ.

North D. 1990. Institutions, Institutional Change, and Economic Performance. New York: Cambridge Univ. Press

North D. 1995. The new institutional economics and Third World development. In The New Institutional Economics and Third World Development, ed. J Harriss, J Hunter, CM Lewis, pp. 17-26. New York: Routledge

North D, Thomas R. 1973. The Rise of the Western World. New York: Cambridge Univ. Press

O’Brien K, Li L. 2006. Rightful Resistance in Rural China. New York: Cambridge Univ. Press

Oi J. 1992. Fiscal reform and the economic foundations of local state corporatism in China. World Polit. 45:99-126

Oi J. 1995. The role of the local state in China's transitional economy. China Q. 144:1132-49

Oi J. 1999. Rural China Takes Off: Institutional Foundations of Economic Reform. Berkeley: Univ. Calif. Press

Oi JC, Walder A, eds. 1999. Property Rights and Economic Reform in China. Stanford, CA: Stanford Univ. Press

Perkins D. 1977. Rural Small-Scale Industry in the People's Republic of China. Berkeley: Univ. Calif. Press

Perkins D. 2004. China's economic growth in historical and international perspective. Presented at Perspective of the Chinese Economy: Opportunities and Challenges, China Cent. Econ. Res., Peking Univ., Sept. 16

Pomeranz K. 2000. The Great Divergence: China, Europe, and the Making of the Modern World Economy. Princeton, NJ: Princeton Univ. Press

Popov V. 2007. Shock therapy versus gradualism reconsidered: lessons from transition economies after 15 years of reforms. Comp. Econ. Stud. 49:1-31

Prosterman R. 2001. Land tenure, food security, and rural development in China. Development 44:79-84

Przeworski A, Alvarez M, Cheibub J, Limongi F. 2000. Democracy and Development: Political Institutions and Material Well-Being in the World, 1950-1990. New York: Cambridge Univ. Press

Rawski TG. 1989. Economic Growth in Prewar China. Berkeley: Univ. Calif. Press

Rawski TG. 1999. Reforming China's economy: What have we learned? China 7. 41:139-56

Rawski TG. 2007. Social capabilities and Chinese economic growth. In Social Change in Contemporary China: C.K. Yang and the Concept of Institutional Diffusion, ed. W Tang, B Holzner, pp. 89-103. Pittsburgh, PA: Univ. Pittsburgh Press 
Redding SG. 1990. The Spirit of Chinese Capitalism. New York: de Gruyter

Rodrik D. 2007. One Economics, Many Recipes. Princeton, NJ: Princeton Univ. Press

Rodrik D. 2008. A practical approach to formulating growth strategies. See Serra \& Stiglitz 2008, pp. 356-82

Rozman G, ed. 1981. The Modernization of China. New York: Free Press

Ruf GA. 1999. Collective enterprise and property rights in a Sichuan village: the rise and decline of managerial corporatism. See Oi \& Walder 1999, pp. 27-48

Sachs J, Woo WT. 1994. Structural factors in the economic reforms of China, Eastern Europe, and the former Soviet Union. Econ. Policy 18:102-45

Sanders R, Chen Y. 2005. On privatisation and property rights: Should China go down the road to outright privatisation? 7. Chin. Econ. Bus. Stud. 3:231-45

Scott J. 1998. Seeing Like a State. New Haven, CT: Yale Univ. Press

Serra N, Stiglitz JE, eds. 2008. The Washington Consensus Reconsidered: Towards a New Global Governance. New York: Oxford Univ. Press

Shirk S. 1984. The decline of virtuocracy in China. In Class and Social Stratification in Post-Revolution China, ed. JL Watson, pp. 56-83. New York: Cambridge Univ. Press

Stiglitz JE. 1994. Whither Socialism? Cambridge, MA: MIT Press

Stiglitz JE. 2008. Is there a post-Washington consensus consensus? See Serra \& Stiglitz 2008, pp. 41-57

Sugihara K. 2003. The East Asian path of economic development: a long-term perspective. In The Resurgence of East Asia: 500, 150, and 50 Year Perspectives, ed. G Arrighi, T Hamashita, M Seldon, pp. 78-124. New York: Routledge

Szelényi I. 1988. Socialist Entrepreneurs: Embourgeoisement in Rural Hungary. Madison: Univ. Wis. Press Vogel E. 1989. One Step Ahead in China: Guangdong under Reform. Cambridge, MA: Harvard Univ. Press

Vogel E. 1991. The Four Little Dragons: The Spread of Industrialization in East Asia. Cambridge, MA: Harvard Univ. Press

Wade R. 1990. Governing the Market: Economic Theory and the Role of Government in East Asian Industrialization. Princeton, NJ: Princeton Univ. Press

Walder AG. 1995. Local governments as industrial firms: an organizational analysis of China's transitional economy. Am. 7. Sociol. 101:263-301

Walder AG, Oi JC. 1999. Property rights in the Chinese economy: contours of the process of change. See Oi \& Walder 1999, pp. 1-24

Wang F, Mason A. 2005. Demographic dividend and prospects for economic development in China. Work. Pap., UN Popul. Div., New York, July

Weber M. 1930. The Protestant Ethic and the Spirit of Capitalism. London: Allen \& Unwin

Weber M. 1951. The Religion of China: Confucianism and Taoism. New York: Free Press

Wejnert B. 2005. Diffusion, development, and democracy, 1800-1999. Am. Sociol. Rev. 70:53-81

Whyte MK. 1996. The Chinese family and economic development: Obstacle or engine? Econ. Dev. Cult. Change 45:1-30

Whyte MK. 2007. A sociological perspective on China's development record. Presented at Rule and Reform in the Giants: China and India Compared, Harvard Univ., Cambridge, MA, Nov. 30-Dec. 2

Whyte MK. 2010. Myth of the Social Volcano: Perceptions of Inequality and Distributive Injustice in Contemporary China. Stanford, CA: Stanford Univ. Press. In press

Williamson J. 1990. Latin American Adjustment: How Much Has Happened? Washington, DC: Inst. Int. Econ. Williamson J. 2008. A short history of the Washington consensus. See Serra \& Stiglitz 2008, pp. 14-30

Wong SL. 1998. Modernization and Chinese Entrepreneurship. Singapore: Natl. Univ. Singapore Press

Woo WT. 1999. The real reasons for China's growth. China f. 41:115-38

Wu JL. 2006. The road ahead for capitalism in China. McKinsey Q. (Special ed.), pp. 116-20

Wu JL, Zhao RW. 1987. The dual pricing system in China's industry. F. Comp. Econ. 11:309-18

Yang DL. 1996. Calamity and Reform in China. Stanford, CA: Stanford Univ. Press

Yang DL. 2004. Has Corruption Peaked in China? Singapore: Natl. Univ. Singapore Press

Zweig D. 1997. Freeing China's Farmers: Rural Restructuring in the Reform Era. Armonk, NY: M.E. Sharpe 


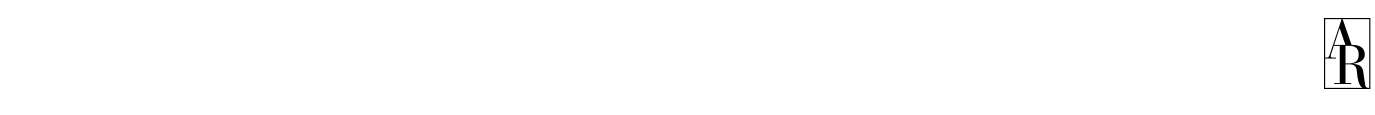

\section{Contents}

Annual Review of Sociology

Volume 35, 2009

Frontispiece

Herbert 7. Gans ...................................................... xiv

\section{Prefatory Chapters}

Working in Six Research Areas: A Multi-Field Sociological Career Herbert 7. Gans ........................................................ 1

\section{Theory and Methods}

Ethnicity, Race, and Nationalism

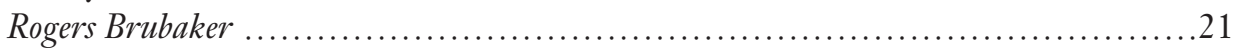

Interdisciplinarity: A Critical Assessment Ferry A. Facobs and Scott Frickel

Nonparametric Methods for Modeling Nonlinearity in Regression Analysis

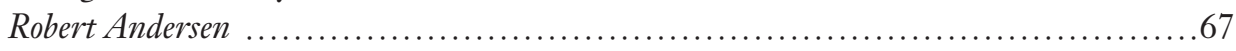

Gender Ideology: Components, Predictors, and Consequences

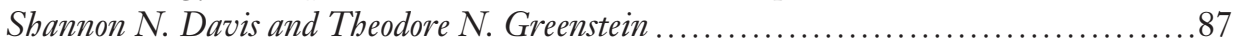

Genetics and Social Inquiry Feremy Freese and Sara Shostak

\section{Social Processes}

Race Mixture: Boundary Crossing in Comparative Perspective Edward E. Telles and Christina A. Sue

The Sociology of Emotional Labor

Amy S. Wharton

Societal Responses toTerrorist Attacks

Seymour Spilerman and Guy Stecklov

Intergenerational Family Relations in Adulthood: Patterns, Variations, and Implications in the Contemporary United States

Teresa Toguchi Swartz 


\section{Institutions and Culture}

Sociology of Sex Work

Ronald Weitzer

The Sociology of War and the Military

Meyer Kestnbaum

Socioeconomic Attainments of Asian Americans

Arthur Sakamoto, Kimberly A. Goyette, and ChangHwan Kim

Men, Masculinity, and Manhood Acts

Douglas Schrock and Michael Schwalbe

\section{Formal Organizations}

American Trade Unions and Data Limitations: A New Agenda for Labor Studies

Caleb Soutbworth and Fudith Stepan-Norris

Outsourcing and the Changing Nature of Work

Alison Davis-Blake and Foseph P. Broschak ...

Taming Prometheus: Talk About Safety and Culture

Susan S. Silbey

Political and Economic Sociology

Paradoxes of China's Economic Boom

Martin King Whyte

Political Sociology and Social Movements

Andrew G. Walder

\section{Differentiation and Stratification}

New Directions in Life Course Research

Karl Ulrich Mayer

Is America Fragmenting?

Claude S. Fischer and Greggor Mattson

Switching Social Contexts: The Effects of Housing Mobility and

School Choice Programs on Youth Outcomes

Stefanie DeLuca and Elizabeth Dayton

Income Inequality and Social Dysfunction

Richard G. Wilkinson and Kate E. Pickett...

Educational Assortative Marriage in Comparative Perspective

Hans-Peter Blossfeld 


\section{Individual and Society}

Nonhumans in Social Interaction

Karen A. Cerulo

\section{Demography}

Social Class Differentials in Health and Mortality: Patterns and Explanations in Comparative Perspective

Irma T. Elo

\section{Policy}

The Impacts of Wal-Mart: The Rise and Consequences of the World's Dominant Retailer

Gary Gereffi and Michelle Christian

\section{Indexes}

Cumulative Index of Contributing Authors, Volumes 26-35 ................... 593

Cumulative Index of Chapter Titles, Volumes 26-35 ........................ 597

\section{Errata}

An online log of corrections to Annual Review of Sociology articles may be found at http://soc.annualreviews.org/errata.shtml 